\section{The fate and biogeochemical cycling of viral elements}

\section{Rui Zhang, Wei Wei and Lanlan Cai}

In a recent Analysis article (The elemental composition of virus particles: implications for marine biogeochemical cycles. Nature Rev. Microbiol. 12, 519-528 (2014)) ${ }^{1}$, Jover et al. highlight the generally overlooked potential biogeochemical importance of the elements that are bound in virus particles. Here, we wish to discuss the fate of marine virioplankton (that is, free virus particles in the water column), which further extends our knowledge of the biogeochemical cycling of the elements that are present in viral particles in the ocean.

After being released into seawater, virus particles face complex environmental conditions before they successfully encounter their specific hosts and start a new life cycle ${ }^{2-4}$. Most viruses are impeded from establishing a new infection and, in natural seawater, a major loss of infectivity and decay of viral particles is observed over periods of hours and days ${ }^{2-4}$. This rapid turnover rate of marine virioplankton suggests that the chemical elements within these particles also undergo fast and active cycling. Jover et al. suggest that these elements, particularly phosphorus, could make a considerable contribution to marine elemental reservoirs ${ }^{1}$. In fact, the direction of flow and biogeochemical cycling of these elements depends on the fate of the virioplankton (FIC. 1), which is determined by different biological, chemical and physical factors.

UV irradiation (especially UV-B irradiation) has been considered to be one of the main causative factors responsible for the presence of defective viruses in surface marine environments ${ }^{5,6}$. An average loss of viral infectivity of 0.2 per hour has been observed under full sunlight for a diverse range of marine virus isolates ${ }^{4}$. Although solar radiation mainly decreases viral infectivity, extracellular enzymes produced by bacterioplankton and other microorganisms degrade viral particles, and the viral components therein (mainly protein and nucleic acid) are released into the marine dissolved organic matter (DOM) pool and can be utilized by bacterioplankton and cycled within the microbial loop ${ }^{7}$ (FIG. 1). It is evident that direct or indirect grazing by protists (for example, phagotrophic flagellates)

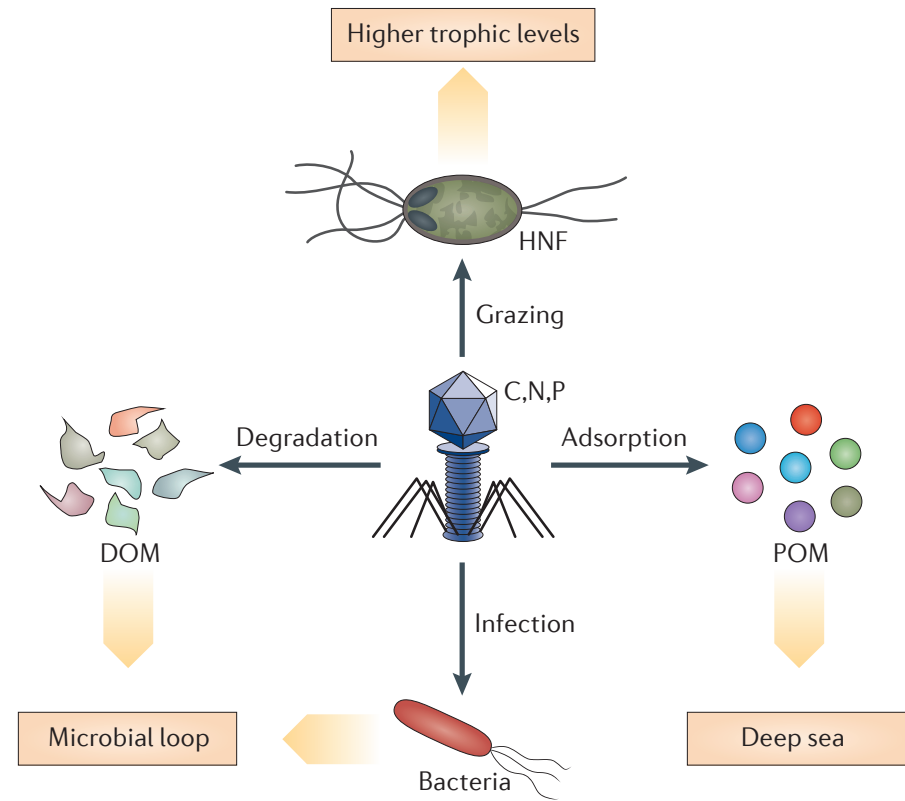

Figure 1 | Schematic illustration of the fate of viral particles in the upper ocean. Elements that are present in viral particles will enter the microbial loop via degradation, classical marine food webs via grazing and the deep ocean via adsorption. DOM, dissolved organic matter; C,N,P, carbon, nitrogen, phosphorus; HNF, heterotrophic nanoflagellate; POM, particulate organic matter.

contributes to the removal of viruses ${ }^{8,9}$, which acts as top-down control for virioplankton and transfers the viral component to higher trophic levels of the marine food web (FIG. 1). The effects of grazing on the removal of viral particles are more significant in eutrophic than in oligotrophic waters and depend on the abundance of both viruses and protists ${ }^{8,9}$. The viral components and elements that are transferred into the microbial loop and food web are mainly cycled locally. However, viral particles will also be absorbed onto particles (for example, particular organic matter or transparent exopolymeric particles) and then vertically settle down to the deep ocean ${ }^{2-4}$ (FIG. 1) or are transported laterally with the water mass. This accounts for the removal of a substantial proportion (up to $34 \%$ in the coastal Mediterranean Sea) of free-living viral particles from the water column ${ }^{6,9}$ and should drive a large amount of viral materials away from local biogeochemical cycling.

Although several studies have shown that viral particles are abundant in bathypelagic waters ${ }^{10-12}$, the source and fate of these deep sea viruses are unclear. Compared with surface waters, the decay rate of virioplankton in the deep sea is decreased by two to three orders of magnitude, which might contribute - at least partially - to the high number of viruses in the deep sea ${ }^{10,13}$. Very limited measurements of viral production and the decay rate have suggested allochthonous inputs of viruses, on sedimentation particles, to the deep sea ${ }^{9-13}$. Nevertheless, as an organic form, the elemental constituents of viruses should be more important in the deep sea than in the upper ocean as most DOM in the deep sea is refractory ${ }^{14}$. In this sense, unlike their generally recognized top-down role in microbial ecosystems, in oligotrophic deep seas viral particles can be regarded as 'bottom-up' agents, partially fertilizing the microbial loop. More investigations are urged to elucidate the biogeochemical role of viruses in the deep ocean.

Rui Zhang, Wei Wei and Lanlan Cai are at the State Key Laboratory of Marine Environmental Science and the Institute of Marine Microbes and Ecospheres, Xiamen University (Xiang'an), Xiamen 361102, China.

Correspondence to R.Z. e-mail: ruizhang@xmu.edu.cn

1. Jover, L. F., Effler, T. C., Buchan, A., Wilhelm, S. W. \& Weitz, J. S. The elemental composition of virus particles: implications for marine biogeochemical cycles. Nature Rev. Microbiol. 12, 519-528 (2014). 2. Weinbauer, M. G. Ecology of prokaryotic viruses. FEMS Microbiol. Rev. 28, 127-181 (2004).

3. Wommack, K. E. \& Colwell, R. R. Virioplankton: viruses in aquatic ecosystems. Microbiol. Mol. Biol. Rev. 64, 69-114 (2000).

4. Mojica, K. D. \& Brussaard, C. P. Factors affecting virus dynamics and microbial host-virus interactions in marine environments. FEMS Microbiol. Ecol. 89, 495-515 (2014). 
CORRESPONDENCE

5. Suttle, C. A. \& Chen, F. Mechanisms and rates of decay of marine viruses in seawater. Appl. Environ.

Microbiol. 58, 3721-3729 (1992).

6. Noble, R. T. \& Fuhrman, J. A. Virus decay and its causes in coastal waters. Appl. Environ. Microbiol. 63 77-83 (1997).

7. Noble, R. T. \& Fuhrman, J. A. Breakdown and microbial uptake of marine viruses and other lysis products. Aquat. Microb. Ecol. 20, 1-11 (1999).

8. Gonzalez, J. \& Suttle, C. Grazing by marine nanoflagellates on viruses and virus-sized particles: ingestion and digestion. Mar. Ecol. Prog. Ser. 94, 1-10 (1993).

9. Bongiorni, L., Magagnini, M., Armeni, M., Noble, R. \& Danovaro, R. Viral production, decay rates, and life strategies along a trophic gradient in the North Adriatic Sea. Appl. Environ. Microbiol. 71 6644-6650 (2005).

10 Arístegui, J., Gasol, J. M., Duarte, C. M. \& Herndl, G. Microbial oceanography of the dark ocean's pelagic realm. Limnol. Oceanogr. 54, 1501-1529 (2009).

11. de Corte, D., Sintes, E., Yokokawa, T., Reinthaler, T. \& Herndl, G. J. Links between viruses and prokaryotes throughout the water column along a North Atlantic latitudinal transect. ISME J. 6, 1566-1577 (2012).

12. Li, Y. et al. Examination of the role of the microbial

loop in regulating lake nutrient stoichiometry and

phytoplankton dynamics. Biogeosciences 11 , 2939-2960 (2014).

13. Parada, V., Sintes, E. \& van Aken, H. M. Viral abundance, decay, and diversity in the meso-and bathypelagic waters of the North Atlantic. Appl. Environ. Microbiol. 73, 4429-4438 (2007).

14. Jiao, N. et al. Microbial production of recalcitrant dissolved organic matter: long-term carbon storage in the global ocean. Nature Rev. Microbiol. 8, 593-599 (2010).

\section{Acknowledgements}

Comments from Feng Chen were appreciated. Financial support is provided by the 973 program (2013CB955700) and NSFC (41376132.) to R.Z

\section{Competing interests statement}

The authors declare no competing interests. 